\title{
A PHONETIC AND MORPHOLOGICAL INTERPRETATION OF ZIMMERMANN'S AFFIX 61 IN THE MAYA HIEROGLYPHIC CODICES
}

By John Fought

In this paper I propose a decipherment of Zimmermann's affix 61 as -al when subfixed or postfixed to a main sign in the codices. ${ }^{1}$ The 102 glyph groups listed in the figures below include all the codical occurrences of 61 and one example from Landa's Relación (Fig. 34).

Affix 61 is the so-called 'bundle' affix, which Gates called the 'table of honor glyph'. The divergence of these ideographic readings from each other and from the phonetic approach used here calls for some remarks on the problem of decipherment. Productive ideographic or pictographic readings of Maya hieroglyphs have been proposed, and are now generally accepted by Mayanists. It is not my intention to minimize the value or credibility of such identifications when the glyph is related to a known item of Maya culture and to an attested

${ }^{1}$ Hieroglyphs are identified here by Zimmermann's catalogue numbers. References to figures, unless otherwise specified, are to those at the end of this paper. Maya forms in citations of published materials are not normalized; others are transcribed in a broad phonetic notation which indicates glottal stop and the glottal element of 'glottalized consonants' by [?]. Page references to well known dictionaries are omitted.

This paper would not have been written without the guidance and encouragement of Floyd G. Lounsbury and the advice of Michael D. Coe. I wish to acknowledge the generous loan of Henry Allen Gleason's personal files of Maya vocabulary: unless other attribution is made, Maya forms are taken from these files.

Though I have profited from discussion of many points, the responsibility for the findings presented below is my own. 
Maya linguistic form, as are pictures of gods, animal figures, and the like. But this is seldom possible when the glyph is an affix. The object represented, if any, is obscure in most cases, so that labels like those just mentioned are probably more relevant to our own culture than to the Maya's.

A more fruitful approach involves matching the affixes of the modern Maya languages against the glyph to be deciphered, until a particular pairing emerges as most probable. If such a decipherment is to be acceptable, it must meet two minimum conditions:

(1) It must be indicated clearly and positively in some probative context.

(2) It must yield grammatical, meaningful, and contextually plausible results in every context where the neighboring glyphs have been dependably deciphered.

It is not easy to meet these conditions in the present state of Maya studies, since detailed comparative studies of the modern Maya languages and complete distributional studies of the hieroglyphs are unavailable. It is no less true, however, that failure to meet them weakens a decipherment, however it was originally conceived. Even the arabic numerals, often cited as a familiar ideographic system, are quite arbitrarily related to the arithmetic units they denote and to the linguistic forms they represent. A decipherment of the sign 80 in a French text, for example, must capture the structure of quatre-vingts 'four twenties' as opposed to our eighty 'eight tens' if it is to be fully satisfactory. It is these linguistic forms which are the chief object of decipherment, for only through them is an accurate and complete understanding of the text made possible. Only when this has been achieved can the working of the writing system be described in detail. In this study, decipherment means the matching of a hieroglyph with the Maya linguistic form or forms it represents, and the translation of these forms, with whatever grammatical information is relevant.

Since modern Maya derivational and inflectional suffixes contrast in many environments, and since sequences of two or more affixes are common, several affixes may be productive readings of a particular affix glyph in those contexts where the environment has known readings. Without a probative or diagnostic context which eliminates all but one of these, there is no real basis for choosing among the competing readings. 
Conversely, a reading based on a single probative context, if it is not tested in all the known contexts, remains in some degree conjectural. With our limited knowledge of the writing system, few contexts are decisive in and of themselves. A reading is therefore demonstrated far more convincingly by the convergence of a probative context and a set of corroborative contexts than by either of these alone.

Thomas Barthel's reading of affix 79 as -al, besides being directly relevant to this study, is worth examining as an illustration. His proposal is based on the following four collocations:

' 1 . We often meet the sign for heaven (caan) with suffix 79. From the post-Columbian books of Chilam Balam and the lexigraphical material, the expression caanal (Motul, p. 17] canal subida, en lo alto, cosa alta) is well known. Furthermore, in some clauses of the Dresden Codex $(32 c, 36 a, 36 b)$ the locative affix 72 (Thompson's 'ti') is prefixed, which makes the reading $t i$ caanal plausible.

'2. The known sign for "day" or "sun" (kin) is sometimes found in connection with the minor element 79 (D. 38c, 53a, $54 \mathrm{~b})$. Working with a hypothetical phonetic value "al", we arrive at the word for "heat" (kinal) (Motul, p. 513 el calor), which seems to fit in the adjacent passage - an unfavorable augury.

'3. In the weather almanac in Dresden 71-73 the sign for "wind" (ik) can be seen with affix 79 prefixed. The suffix 78 might in other contexts signify the word for "bean" (bul). A reading of this glyph as bulikal (stormy weather, Motul, p. 159 tormenta) is tempting.

'4. In the ritual calendar Dresden $5 \mathrm{~b}$ is depicted a deity with the emblems of death. The corresponding nominal glyph is built up with a head as main sign, affix 79 as lower jaw, and the familiar sign for death (cimi) on the cheek. The reading cimal "the dead one" seems quite possible."

This argument is questionable at several points. The third collocation is read backwards without explanation. The context, on D. $71-3 c$, shows two examples of the group in question,

2 Thomas Barthel, 'Maya Epigraphy: Some Remarks on the Affix -al,' Pro. ceedings of the Thirtieth International Congress of Americanists, p. 48. Cambridge, 1952. 
79.1322:78, with dotted patterns often interpreted as rain descending from each. It may have been these dots which suggested the reading offered, but they are also found below two other groups in the context, and may bc a part of the pictures rather than the text.

Barthel treats only these four collocations, omitting one which is often regarded as probative. Kelley writes: 'Z79 es más bien un glifo problemático en cada caso, y parece usarse o no sin ninguna diferencia obvia en el significado. . Thompson ha sugerido que $Z 79$ podría leerse como te por su aparente relación con Z82. Barthel (1952) dedicé un artículo a Z79 en el que sugiere que se lea como al. El único caso de absoluta discordancia en la interpretación de Barthel es precisamente en el grupo de glifos para Itzamna."

In my opinion, the omission of this group, 13.146:79, a nominal for God D, the consideration of only four of the occurrences of 79, one of the more frenquent affixes, and the unexplained reversal of the usual orden of reading in one group outweigh any merit the proposal might have in the three remaining cases, in spite of Thompson's rejection of his own reading in favor of Barthel's.

It should be noted in passing that the occurrence of a main sign with and without affixes, mentioned by Kelly in the preceding passage, is not prima facie evidence for the insignificance of the affix glyphs. It is more likely to be scribal abbreviation. or contrast, as in Yucatec tšupal 'girl', tšupalal 'girls', or syntactically governed alternation, as in Tzotzil lum 'earth', alumal 'your country'. Those cases where the affix makes no obvious difference may be expected to fall into one or another of these categories on further analysis.

Knorozov has proposed two readings of affix $61:$ as $-n$ in collocation with 1333a, Landa's $i$, and as $-h(e)$ with 1331 . The first of these is based on a context, M94-5c, where a woman is depicted eight times, each time with a bird on her shoulders. Though Tozzer and Villacorta disagree on some of these, both identify an owl on 95c. The clause above this picture begins with the group 1333a:61, which Knorozov reads 'ichin (in?) moderno icin, lechuza." He apparently reasoned that since the

3 David H. Kelley, 'Fonetismo en la escritura Maya', Estudios de Cultura Maya 2.296. 1962.

+ Yuri Knorozor, La escritura de los antiguos mayas, ґ. 79. Moscow, 1955. 
word for owl begins with $i$ and has two syllables, and the glyph group begins with Landa's $i$ and has two glyphs, that this must be the group for 'owl'. This is quite reasonable, but the known glyph groups for macaw, quetzal, turkey, vulture, and muan do not appear in the text above those pictures, and indeed there is no reason to assume that the pictured birds are named in the text at all. Certainly the context is not probative, and the decipherment ikim (Knorozov posits alternation of $m$ and $n$ ) is possible but not necessary.

As a consequence of the above, the decipherment of the group 1333a: 61-1339 (Figure 34) is suspect as well. This group is found in Landa, as a form of the month Chen. ${ }^{5}$ His readings is:

'ichin, fuente (compárese ichinah, lavarse. Mot.). ${ }^{6}$

In collocations with 1331, the Chuen day sign, Knorozov proposes a reading $-h(e)$ bascd on the group 25:1331:61 (Figure 55), which he reads 'ah keh, el señor del mes'.

On Dresden 69. this group appears before one composed of the $y a^{\check{s}}$ 'green' glyph and the head of the Chicchan god (cf. Thompson 1960, Figure 42.19). Again, Knorozov has rejected the simple in favor of the original: lower on the same page the group IV.1331:61 (Figure 58) appears as ' 4 uinal' in a distance number. Gates remarked of this group:

'The use of this glyph as denoting the vinal on the monuments has become fully established. It can also hardly be doubted that with the subfix [61] it has the technical meaning 'vinal' in the codices; in two cases the evidence here is quite direct: Dr. 72a.29, f.29. D.61 and 69. Here we have an unmistakable time count of 15.9-1.3 and 15.9-4.4, with our glyph 11.2 in the vinal position."

Thompson follows Gates, who follows Seler, in rejecting a derivation of uinal from $u$ 'moon'. ${ }^{9}$ Thompson, however, ment. ions the form uen: "with the meaning of a matter of a month

5 Alferd M. Toz\%er, Landa's Relación de las cosas de Yucatán, Papers of the Peabody Museum of American Archaeology and Ethnology, vol. 18, p. 160. Cam. bridge, 1941.

6 Knorozov, Escritura, p. 79.

7 Knorozov, Escritura, p. 77.

8 William Gates, An Outline Dictionary of Maya Glyphs, p. 37. Maya Society Publication N"1. Baltimore, 1931.

○ J. Eric S. Thompson, Maya Hieroglyphic $\mathbb{W}^{\prime}$ riting ${ }^{2}$, p. 143. Norman, Okla., 1960; and Gates, Dictinnary, p. 90. 
or months, with examples given as hun uen ual "my [her] child is one month old", ho uen in paalil "my child is five months old." The word uen appears to be associated with the moon, for ucn uinic is an albino, and albinos are associated with eclipses. ${ }^{10}$

The form uen is most probably u-en, 'moon' and the $-V n$ 'substantive' suffix: in Berlin's analysis of Tzeltal, this morpheme has allomorphs in, en and an, conditioned by the preceding vowel, and occurring after noun and 'unknown' class roots, forming derived nouns and adjectives. ${ }^{11}$ That this suffix occurs before the -al 'substantive' is shown, e.g. by Barthel's caanal, so that a tentative segmentation $u$-in-al of the form uinal does not appear forced.

At the same time, it is not essential to the argument of this paper: uinal ends in -al, and could be represented by an -al glyph whatever its morphemic constituency.

Of the $-V I$ 'substantive' suffix, Knorozov writes, '- 1 precedida de vocal que coincide con la vocal de la raíz. (es decir, que obedece a la ley del sinarmonismo), es un sufijo de derivación que forma nombres y verbos de voz neutra. Probablemente, en la antigüedad, ese sufijo tenía una vocal determinada..."

It is not clear to what stage or dialect of Maya this principle of synharmony was meant to apply. Knorozov does not adhere to it rigorously in decipherments, and while modern Yucatec perhaps approaches vowel synharmony most closely, it offers many examples of other patterns:
tin yakun-t-al
'I am being loved'
tin tšen-t-al
'I am listening'
tun mis-t-al
'It is being swept'

Tozzer, from whom these examples are taken, adds in a note that 'The same tendency to use the suffix -al even when the vowel on the stem is not $a$ is seen here as with verbs of class I., ${ }^{13}$

10 Thompson, H'riting, p. 143.

11 Brent Berlin, The Tenejujus Dialect of Tzeltal: A Sketch of Morphology, passim. Stanford, 1961.

12 Knoro\%ov, Escritura, p. 58.

13 Alfred M. Tozzer, A Maya Grammar, vol. 9, pp. 64, 68, 85, Papers of the Jeabody Museum ... Cambridgc, 1921. 
In Tzeltal, and very probably in Maya in general, there are at least two types of vowel alternation, as well as invariable affixes. The table below, freely adapted from Brent Berlin's work, shows the allomorphs of the - $V l_{1}$ 'locative' suffix and of the $-V l_{2}$ 'substantive' suffix, as they occur after noun and intransitive verb roots with each of the five stem vowels. The gaps in the table were examples I did not find:

\section{Some -Vl Affixes in Tzeltal}

(1)

Stem Vowel
$\mathrm{i}$
$\mathrm{e}$
$\mathrm{a}$
$\mathrm{o}$
$\mathrm{u}$

$\begin{array}{cc}N-V l_{1} & N \cdot V l_{2} \\ \text {-il } & \text {-el } \\ \text {-al } & \text {-ol } \\ \text {-el } & \text {-al } \\ - & \text {-al } \\ - & \text {-al }\end{array}$

$V i \cdot V 1_{2}$

-al

-al

-el

- al

- al

As the table shows, the $\cdot V l_{1}$ and $-V l_{2}$ suffixes, in contrast after noun roots, have different vowels in the same environment. None of the patterns of alternation shown can fairly be called synharmonic. Further, the commonest form in the table is -al, as in Yucatec. The principle of synharmony, then, is not confirmed by the linguistic data, which suggest a more complex system of alternations.

It is another thing to posit such a principle as applying to the writing system only. Since readigns based on this principle will naturally tend to support it, it seems wisest to advance such principles with extreme caution, and to test them carefully. The results of this study do not always support synharmony, and lead me to conclude that those examples of it which have been found in the writing system represent a tendency rather than a uniform, systematic rule of Maya orthography.

There appears to be no reason to exclude a reading of 61 as -al, as suggested by the distance-number contexts. Knorozov's reading $-h(e)$ is not explained, and the context on which it is based is not as good as that of the distance numbers.

I propose, then, a reading uinal for 1331:61, Figure 50, and $u$ uinal for Figure 51. Other collocations not containing undeciphered glyphs are Figure 53, kan uinal ' 4 . uinals' and 
Figures 54-5, ah uinal, accepting the reading ah, a personal prefix, for prefix 25, with Kelly and Knorozov. ${ }^{14}$ We must now examine the other collocations of affix 61 with glyphs whose values are accepted.

Glyph 109, the nominal sign for Goddess I, is usually interpreted as the young Moon Goddess. Knorozov and Kelley decipher the glyph as chup 'Lady'. ${ }^{15}$ This and similar forms are widely attested in Maya: Yucatec 'tšupal 'girl', and its probable cognates 'kopo 'virgin' and $s$ - 'tšok 'girl', from Ixil and Chol, suggest that the initial of the ancestral form was glottalized, though this is by no means certain. The form $h$ - t $\dot{s}$ sumetik from Tzeltal is glossed 'the Moon, Mother of God' and contains the honorific plural -etik known from other forms. ${ }^{16}$

The difference between ?tšup- and ${ }^{t} t s u m$ - may be morphological, as between Yucatec yekab 'offer' and kam 'an offer. ing', or it may be a matter of phonological correspondence between Tzeltal and the other languages. The forms are obviously related very closely in either case, and the Tzeltal form provides a valuable documentary link in the 'tšup 'Lady' decipherment, though the Moon Goddess may well be endowed with Catholic attributes for the modern Tzeltal. Accordingly, I read Figure 27, 109.61, as 'tsupal 'Lady', and Figure 28, 21.109.61, as sak 'tšupal 'White Lady', or any of the other meanings associated with prefix 21 .

14 David H. Kelley, 'A History of the Decipherment of Maya Script,' Anthropological Linguistics, vol. 4, $\mathrm{n}^{\circ}$ 8, p. 42, 1962. Neither Kelley nor Knorozov discusses the use of prefix 25, Thompson's 'spectacle glyph,' with reference to the seating of calendrical periods. Figures 54 and 55 here are found in the Dresden tcxt in the 'serpent number' sections (D.61-2, D. 69) where such a usage should ccrtainly be investigated. I regrct that I can contribute nothing to the discussion in Thompson, Writing ${ }^{2}$, pp. 119-20, beyond the suggestion that the word for the time period with a personal prefix, in this casc ah uinal, is a plausible way of referring to the whole period, and hence also to its beginning or end.

15 Kelley, 'History,' p. 30.

16 Berlin, Tzeltal, p. 45.

$16^{2}$ Lounsbury points out (personal communication) the resemblance of prefix 15 to Landa's second ' $u$,' and suggests that it may be a phonetic-semantic determinative $u$ 'moon' used instead of affix $1, u$ 'its' (third person singular possc.sive pronoun), since affix 1 had become specialized as a grammatical marker to an extent which prohibited its use as a determinative. This convincing interpretation leads me to revise the reading of figures 29 and 30 to " 'isupxl 'Mloon Lady.' 
Zimmermann's affix 15, found in Figures 29 and 30, occurs only before glyph 109, and is graphically similar to the infixed 'lock of hair' element in 109. If 15 has a phonetic reading, it remains obscure: the $\check{s}$ - prefix in the Maya example, like the $h$ - prefix, is a personal marker of very high textual frequency, and would therefore not be represented in the codices by the rare 15 glyph alone. It is possible that what Zimmerman catalogues as 15.109 is simply a scribal variant of 109. Figures 29 and 30, exclusive of prefix 15, are read 2 tšupal.

The group 160:61-1333a, Figure 41, appears four times on Madrid 93c, each time above a picture showing a woman apparently sprinkling drops of water over a child scated before her. It has long been translated 'baptize' and taken to refer to a similar ritual mentioned by Landa and more recent observers. Landa give caput zihil 'to be reborn' as the native term for the practice. ${ }^{17}$ It is also found in the Spanish-Maya section of the Motul, under baptizarse.

The Motul lists oća and oc haa as 'baptize'. Based on ok 'enter', these are literally 'enter water', and neither they nor Landa's term is an acceptable decipherment of Figure $41:$ glyph 160 must be read as tšeh or some similar form on the basis of the group 160:1341:62, read tši kinil 'West', and the daynames corresponding to Yucatec Manik, in Jacaltec, $t \check{s} e$, in Ixil, ise, and in Chuj, the cognate keh, all meaning 'deer'. ${ }^{18}$

Knorozov's reading is closer to the mark, though it ignores 61 entirely: 'chehi, riega (compárese cheh, gota de agua, Mot.)'. ${ }^{\text {1n }}$ The Motul actually lists $c h$ ' $\mathrm{ch}$, with glottalized initial. In the Spanish-Maya section there is a listing ch'ahal haa 'gotear', or 'to drip', and Tozzer assembled tšahal, 'tšahal, tšahal. haa, and 2 tsahal haa, all with this same meaning. ${ }^{20}$ The decipherment I propose is tšehali 'it is sprinkling' or perhaps 'she is sprinkling'. While the evidence is not conclusive on the vowel of 160 , its other uses lead me to consider - $e$ - preferable to $-a$ given the appearance of both vowels in the Motul.

The suffix $-i$, here represented by 1333a, Landa's $i$, has been variously treated in the grammars I nave consulted. Tozzer treats it twice, first: "When the verbal pronoun is used as the

17 Tozzer, Landa, pp. $102 \mathrm{ff}$.

18 Sce Thompson, $\mathbb{K}^{\prime}$ riting, ก. 68, and Kelley, 'History,' p|r. 25.6.

13 Knorozov, Escritura, p. 91.

20 Tozzer, Grammus, p. 296. 
subject of an intransitive verb in the past tenses an $i$ is used to express the third person. kim-en I died. kim-i He died." ${ }^{\text {I }}$ And again: 'The particle -il, noted above, may be used with the negative coming, however, after the verbal pronoun: ma sak-en-il I was not afraid. The final $l$ is often lost and we get: ma sak. en-i. ma bin-en-i I did not go.' He notes on the same page that Iópez has this $-i$ in ' $m a$ in çat hanali I do not desire to eat."'

Castillo writes of this same suffix: 'El morfema sufijado $-i$ ' no ha sido analizado con precisión: parece tener un valor determinante, es decir, es un morfema determinador. ${ }^{23}$

Though the precise grammatical status of this affix remains obscure, it does occur after the -al affix.

Glyph 169, the nominal of God B, is usually read Chac. In Figure 9, 169:61-1333a, there is another example of the $-i$ suffix after 61. Chac and similar forms in Modern Maya often mean 'rain' or 'storm', as in Solís Alcalá, chaac 'rain, chacikal 'rainstorm', kam chaac 'downpour', and the Motul, chacal han 'rain', chacal ik 'storm'. In Gleason's files are Yucatec tsàák 'rain' and Tzotzil tašak ho? 'rain'. The Tzotzil form suggests that the others are syncopated forms of an ancestral *tašak, but this must remain conjectural until more abundant comparative materials are available.

Whether 169 is interpreted as a nominal sign for God B or as a rebus writing for rain, the reading tšakal for Figures 1.2 is equally plausible. But Figure 10, 169.61/1339, matches the entry chacal haa 'rain' in the Motul. Haab 'year' or 'water' is one widely accepted reading of 1339. Morphologically, this form is almost certainly haa-b 'water-plural', ${ }^{23 a}$ very probably referring to the number of years as so many rainy seasons. (Lounsbury, personal communication, cf. counting by winters in temperate zone cultures.)

Other collocations of 169 and 61 which can be deciphered are Figure 3, u tšakal 'its Chac' (cf. Tzotzil alumal 'your country' above), Figure 4, oš tšakal '3 Chac', Figure $6 e^{2} k$ tšakal 'black Chac', and Figures 7-8, yaš tšakal 'green Chac'. With regard to Figure 9, one further possibility exists for a reading tšakali,

21 Tozzer, Crammar, p. 40.

2 Tozzer, Crammar, p. 105.

23 Moisés Romero Castillo, 'Morfemas clasificadores del Maya-Yucateco,' in

A Dilliam Cameron Tounsend, p. 662. Mexico, 1961.

23" Kelley, 'History,' p. 34. 
presumably a verb form: the Motul lists ?tšakal 'cortar con golpe', or 'chop'. The fact that God B is usually represented in the codical pictures brandishing an axe makes this an interesting possibility, in spite of the difference of glottalized initial. We have already seen several examples where forms with and without this glottal element are cognates with identical meanings.

Before presenting the readings I propose for the collocations of 1320, the Ahau day-sign, and 61, it is necessary to consider the group ]320:/34]:62, the 'East' group. Kelley writes: 'En Yucateco, la palabra para Este es lakin o likin. Esta última parece como una simple asimilación de la - $a$ - a la siguiente vocal (no una posibilidad de intercambio entre $-a$ - e $-i$ - como sugirió Cordy). Fisto haría de 1320, la (Knorozov da al Ahau normal el valor fonético $l a$ ), pero pienso que lo más que podemos aceptar es que el Ahau invertido tenga ese valor. Fl Ahau normal significa "señor, jefe" y el Ahau invertido puede tener el mismo valor conceptual. Schuller da como significado de al. la "amo, señor" en Pokomchi. Aun más, la sustitución inversa ocurre en el Mam para taxau-kih, "Este", donde t-ahau reemplaza a la, ${ }^{n+t}$

Note the Mam form: in an unpublished paper, Mrs. Anne F. Rosenthal proposed a reading ahalkin 'the sun rises' for 'East'. 'The $t$ - prefix is very probably the element $t i-\sim t$ - glossed 'dative' by the early grammarians, and mentioned by Tozzer as a preposition. I suspect that it is also a constituent of Tozzer's 'time particles', so that a form such as tin watan 'my wife' might better be glossed 'to-me she-wife'. The Pkih constituent of the Mam form appears to be 'day'; 'sun', as in Pocomchi. I would tentatively equate the ahau- constituent with the verb ahal 'arise', 'awaken', found in the Motul and other dictionaries. There is an affix -au, found in Tzeltal after intransitive verb roots, whose meaning is approximately 'action of', so that the final segmentation of the Mam form is probably t-ah-au ?kih 'toward-rise-action sun', or 'where the sun comes up'. 'Though it is not entirely safe to use grammatical evidence from several Maya languages in this way, the forms in question are all quite widely distributed, and presumably inherited from the parent language.

2t Kelley, 'Fonetismo.' p. 296. 
If the interpretation just given is accepted, there are at least two words for 'East' in the Maya languages. Assuming that the forms which became modern tahau Pkin and lakin were both in use in Classic times, the former in the highlands, the latter in Yucatán, a simple interpretation of the hieroglyphic usage is as follows: 1320 alone, in upright position, was used for Aliau as a nominal sign and a day name, while in inverted position. it was used in the 'East' group with the phonetic value ahau. Inversion of the sign marked its rebus usage for these speakers. I3ut for Maya scribes whose word for 'East' was lakin, the inverted 1320 might easily have acquired the value $l a$, and might be used with that value in other groups by them. It is possible to argue the other way. of course, depending upon one's view of the spread of hicroglyphic writing among the Maya. A study of dated monumental texts might provide a solution.

Turning now to the collocations of 1320 and 61, both ahal and ahaual are grammatically permissible readings so far as I can tcll. The first would mean 'arising' or 'awakening', and the second either 'awakener' or a dependent form of Ahau. Since the contexts provide no basis for choice, I offer three possibilities in each case: Figure 18, ah.(au)al, Figure 19, sal: ah.(au)al, and Figure 20, ah ah.(au)al. Figures 21-23 include undeciphered glyphs.

Figure 32, composed of Landa's $i$ and affix 61, was read icim 'owl' by Knorozov. My reading is ial, a form with several meanings in Maya. The Motul lists yal ah 'pour' and yal 'digit', compounded with 'foot' and 'hand' for 'toe' and 'finger'. Pérez gives yal 'pour' and 'dissolve', and 'Tzeltal has ral 'fall' or 'lower'. ${ }^{20}$ Since this group appears in the passage of the Madrid (94-5c) where a woman is depicted bearing various birds on her shoulders, it would be tempting to suggest a related meaning 'descend', but this would only be a guess. Figure 33, 75.133.33a: 61 , I read ma ial, apparently a negative of one of the verbal meanings.

Though Figure 34, the hieroglyphic spelling of the month Chen give in Landa, is crudely drawn, it appears to be 133.3a: 61-1339, with two loops below the Cauac sign. These may be tentatively identified as affix 64. (cf. Kelly, 'History', p. 35),

2 Brent Berlin and Terence Katufman, Tzeltal Dictionary (n.p., n.d.). 
an affix which occurs with the Caban sign in the "passage of the bees' in the Madrid. The group so formed is widely accepted as cab 'bee', I suggest that it be read in full as cab(ab), with 64 functioning as a phonetic determinative. If I have overlooked a published decipherment to this effect, I apologize: it was first pointed out to me by Professor Coe.

Returning now to the Chen spelling in Landa, two readings are possible: 1333a:61-1339 ial haab, and 1333a:61-1339:64 ial haab(ab) 'falling waters', with and without the phonetic determinative.

Note that Chen is the first of four months, Chen, Yax. Zac, and Ceh in Yucatec, whose hieroglyphic spelling customarily includes a Cauac sign. Thompson (W'riting, ${ }^{26}$ p. 118) notes their connection with the color-direction symbolism, associating Chen with black and west, Yax with green and south, Zar: with white and north, and Ceh with red and east. Before a further connection, with the rainy season and the agricultural cycle, can be maintained, some explanation for the spelling in Landa must be found. The other three months in question appear there with the color sign, as on the monuments, but Chen is aberrant in lacking the 'black' affix.

Glyph 1359 in the collocation IX.1359.1337:61, Figure 65, has been read by Knorozov as zuu, in bolon zuucab 'great sacrifice'. Kelley rejects this - convincingly - in favor of clza in bolon dzacab. " I propose a reading bolon 'tsakabal 'great lineage' for this group, based on the entry racabal 'casta, linaje' in the Motul. If a different segmentation of 1337:64 cab(ab) 'bee' is chosen, however, namely $k a-b$, then readings as bolon tzacal should be considered. The Motul gives tzacal 'search', oácal 'grow', and sacál 'medicine'. I regard the first as preferable to these, however.

Figure 64. 1.1359.61:64, appears in Dresden 29-30b, a context clearly dealing with sacrificial offerings. I regard this group as strongly corroborative of the method of decipherment and the values of the glyphs suggested in this study. The universally accepted value $u$ for affix 1 , the value $\%$ sa for 1359 , as proposed by Kelley, and the values $(a) b$ for 64 and $a l$ for 61 used here, yield a form $u$ 'tsabal, listed in the Motul as the passive participle (in an acceptable, if loose sense) of ' $x a$ 'offer',

2o. Tozacr, Landa, p. 160.

2: Kelley, Fonetismo.' fig. 60, and Knornon, Eseritura, p. 82. 
'give'. An adequate gloss would be 'its being offered', clearly most appropriate to the passage.

Figure 66. 1359i-1360:61, contains the first element of the month sign Mac, and yields a form tsamal. The Motul lists three such forms samál 'cosa aplastada', or 'something flattened, crushed', Jámal 'get wet', and tzamal, glossed 'yr gastando y. consumiendo la comida poco a poco', 'to eat a meal little by little'. The context does not prescribe any one of these meanings. so far as I can tell.

Figure 67, the remaining collocation of 1359 and 61, contains the unread glyph 708, which Zimmermann suggests as a variant of 707 .

Affix 61 occurs twice with 1319, which Thompson has convincingly deciphered as hel 'successor'. 'change'. ${ }^{2 s}$ The contexts in the Madrid are not good, and I find no documentation of a form helal. There is, however, a transitive verb, listed hel ah in the Motul, which might have a form helal 'changing', 'exchanging'.

Figure 16, read *helalka, and Figure 17, read oš *helal, are offered here as possibilities to be explored, rather than as actual decipherments. Figure 16 suggests a possible use of the comb affix 8] : the reading $k a$ is well established for this affix, and in the environment of Figure 16, it recalls the particle mentioned by Tozzer, $k a$ or kah, as a 'defective verb' meaning 'do', which appears after pronouns and as a clause connector. A detailed knowledge of Maya grammar would be needed in order to investigate this possibility, however.

Figure 26 shows a fish, 758, with subfixed 61. Thompson has shown that the fish, Maya šok, is a rebus glyph for 'fish' and 'count'." An inspection of the Motul provides other possible meanings of the form sol, 'obey' and 'respect', and a form sookal (xoocal) 'be counted'. In the context here, however, there is little doubt that the meaning is 'fish', since the preceding tzolkin, D. 29-30b, discussed above, deals with offerings, one of which is a fish, repeated in the following text. Accordingly, I read this group šokal 'fish'.

The decipherment of 707 , the $O c$ day-sign, as ok 'dog', 'enter', 'foot', etc., will probably be revised in the future. The

ss Thomnson, $/$ riting, pp. $160-2$.

20 Thompson, Writing. pp. 162-3. 
ideographic identification, made by Tozzer and Allen, among others, does not account for all the facts, even given the occurrence of a rather rare form ok 'dog' in the Maya area.

Glyph 707 alone is the $O c$ sign, and with affix 62, stands for the month ralled $X u l$ in Yucatec. Thompson's decipherment of IX.707:82 as bolon yocte has been widely accepted. But in Thompson's tables of day and month names, we find that while there is no phonetic similarity between the names ok and $s u l$, the first of these corresponds to Ixil $t s i i$ and to $t s i$ in Quiche and Pocomchi, and the second, to Cakchiquel, Ixil, and Pocomchi tsikin Pkih, all having a syllable tsi in common, whose mean. ing appears to be 'dog': 'The tenth day has the meaning of dog (tzi) in several highland lists, and the glyph itself is the head of an animal which may well be that of a dog; the equivalent day on the Mexican plateau is Itzcuintli "dog". Strangely, the words for dog in Yucatec (pek, ah bil, tzul, bincol) are quite different from the usual $t z i$ or chi which is found in all the other Maya languages and dialects except Huastec, Chontal, and Chicomucelteca. Even Manche Chol, which is so close to Yucatec, uses $t z^{\prime} i$, but Becerra, who does not distinguish between $c$ and $k$, gives ok as Palencano for dog. ${ }^{930}$

Now, if we accept a phonetic reading ok for 707 as a day name, and in bolon yocte, we are bound to accept a reading okil for the month Xul. This form as given in the Motul is a derivative of 'foot', with meanings 'road', 'walking', and 'one who walks'.

Not only has this not been done, but the phonetic similarity of the $t$ si-based forms in the majority of the central Maya languages has not been taken into account.

We have also to consider the question of glottalization. As we have seen several times, the correspondences of glottalized and plain stops in the various languages are not simply and easily predictable. Unless we are prepared to accept Yucatec forms as bases in preference to others, we must accept the possibility that Yucatec ok corresponds to both ok and $o^{2} k$ in the other languages, and that 707 may represent any and all of thern. Note ton that Becerra's form may have been glottalized. This would add meanings 'weep' and 'upon', at least, to the list

3n Thempson, W' riting, p. 78. 
of possible readings of 707 , to judge only by the forms in the Motul.

Though there is every reason to posit forms of the type *okal and *okal, given xoocal and occah in the Motul, I think it wiser to regard 707 as incompletely deciphered, and to await more information on this glyph and the probable readings of it as attestcd in modern Maya. If it should develop that oli or $o P F_{i}$ is after all the correct decipherment of 707, then the readings based on 'foot'. with derived okil, and on 'enter', with derived okol as given in the Motul, appear to be excluded for the collocations of 707 and 6l. This leaves 'weep' and 'upon' as possibilities remaining to be explored.

Of the remaining collocations, a few may be tentatively read. On Madrid 62c there appears a group IV.46.1347:61, shown in Figure 87. Although affix 46 is undeciphered, one supposes from its position here that it may be a classifier. A reading laanal 'high', 'something high', is indicated for the remainder, the only codical example of this collocation (cf. Barthel above).

Figure 13 contains glyph 125, interpreted by Zimmermann as a head variant of God $B$. If this is the case, I would read this group, like the collocations with 169 , as ťsakal. ${ }^{31}$

Figure 35, 1339.61, contains a truncated variant of 1339 . Readings $h a(a) l$ 'water', widely attested in the dictionaries, and hal 'say', 'order', an unattested active of the Motul listing halbal 'be said', 'be ordered', are possible for this group.

Figure 91, 21.27':61, would yield a reading sak itsal from the value implierl by the phonetic group for Itzamna discussed above. I find no form *itsal, but the Motul has itz 'milk', which is also used for 'sap', and appears possible.

To summarize, of the 102 different glyph groups in which 61 is present in the codices, 67 contain one or more undeciphered glyphs. The readings I propose for the remaining 35 groups are found in the following table.

31 Gïnter Zimmermann, Die Hieroglyphen der Masu-ILandschrijten, p. 37. Universität Hamburg, Abhandlungen aus dem Gebiet der Auslandskunde, Band 64 . Hamburg, 1956. 


\section{Fig. Glyph Group Decipherment}

\begin{tabular}{|c|c|c|}
\hline 1. 169.61 & tšakal & 'Chac', 'rain' \\
\hline 2. $169: 61$ & tšakal & 'Chac', 'rain' \\
\hline 1.169 .61 & u-tšakal & 'its Chac' \\
\hline III.169.61 & oš tšakal & '3 Chac' \\
\hline 6. $22.169: 61$ & $\mathrm{e}^{? \mathrm{k}}$ tšakal & 'black Chac' \\
\hline 24.169:61 & yaš tšakal & 'green Chac' \\
\hline 24.169 .61 & yaš tšakal & 'green Chac' \\
\hline $169: 61-1333 a$ & tšakali & 'is storming', 'is chopping' \\
\hline $169.61 / 1339$ & tšakal haa & 'rain' \\
\hline 125.61 & tšakal & 'Chac', 'rain' (?) \\
\hline $1319 ?: 61: 81$ & *helalka & 'changing', 'exchanging' (?) \\
\hline III.1319:61 & oš *helal & '3 changes' $(=$ cycles $)$ (?) \\
\hline $1320 \mathrm{n}: 61$ & $\mathrm{ah}(\mathrm{au}) \mathrm{al}$ & $\begin{array}{l}\text { 'Ahau., 'arising', } \\
\text { 'awakening' }\end{array}$ \\
\hline $21.1320 \mathrm{n}: 61$ & sak ah (au)al & $\begin{array}{l}\text { 'white Ahau', 'arising', } \\
\text { 'awakening' }\end{array}$ \\
\hline $4.1320: 61$ & $-\mathrm{ah}(\mathrm{au}) \mathrm{al}$ & $\begin{array}{l}\text { '-Ahau' 'arising', } \\
\text { 'awakening' }\end{array}$ \\
\hline $758: 61$ & šokal & 'fish' \\
\hline 109.61 & 7 tšupal & 'Lady' \\
\hline 21.109 .61 & sak ?tšupal & 'white Lady' \\
\hline 15.109 .61 & - ?tšupal & '- I Lady' \\
\hline $15.109: 61$ & - ?tšupal & '- Lady' \\
\hline $1333 a: 61$ & ial & 'falling', 'pouring' \\
\hline $75.1333 a: 61$ & ma ial & 'not falling', 'not pouring' \\
\hline $1333 a: 61-1339$ & ial haa & $\begin{array}{l}\text { 'falling waters', 'pouring } \\
\text { waters' }\end{array}$ \\
\hline 1339.61 & ha (a)l & 'water', 'say' \\
\hline $160: 61-1333 a$ & tšehali & 'is sprinkling' \\
\hline 1331.61 & uinal & 'Uinal' \\
\hline $1.1331: 61$ & u-uinal & 'its Uinal' ' \\
\hline
\end{tabular}


Fig. Glyph Group

53. IV.1331:61

54. $25.1331: 61$

55. $25: 1331: 61$

61. $1.1359 .61: 64$

65. IX:1359-1337:61 bolon ?tsacahal

66. 1359i-1360:61 2 tsamal

87. IV.4.6.134.7:61

91. $21.27^{\prime}: 61$ kan uinal

ah.uinal

ah-uinal

u- ?tsabal

sak *itsal kan - kaanal

Decipherment

'4. Uinals'

'the Uinal'

'the Uinal'

'its being offered'

'great lineage', 'high caste'

'crushing', 'wetting', 'chewing'

'4 - high', ' 4 - up'

'white milk', 'white sap'

The 67 undeciphered groups are included for the sake of completeness, and to stimulate the production of new decipherments, since in many of them, only one constituent is undeciphered. While 26 of the readings above represent only the addition of -al to groups of already known value, nine new readings are offered. These are Figures 32-5, 41, 64-6, 87, and 91. Aside from the probative context mentioned above, I find that Figure 4l, tšehali 'is sprinkling' and Figure 64, u-?tsabal 'its heing offered' provide the strongest support for this decipherment of affix 61 , through the convergence of well established readings of the constituent glyphs and apparently close fit in the contexts where they are found.

This decipherment of affix 61 as -al is offered as a hypothesis, to be evaluated for simplicity and productivity in comparison with other proposed readings of affix 61, and of other glyphs as -al. It is noteworthy that in many cases, the results suggest discontinuous reference. While some of the alternatives are less likely to find support than others, I do not regard this as a weakness of the method used: rebus writing is characteristic of logographic systems, and a phonetic approach is best suited to discovering examples of it. As knowledge and proposals accumulate, some will be confirmed, others rejected.

In any event, I feel that the decipherment offered above does meet the conditions imposed earlier, in that it is clearly indicated in one context, excluded in none, and convincingly apt in some. 


\section{Locations}

(1) Figure 1: D. 4a, 5b, 11c, 15b, 16b, 22b, 23a, 29aabbcc, 30abbcc, 31bbcc, $32 \mathrm{bcc}$, 35abcc, 36acc, 37acc, 38acc, 40aabcc, $41 \mathrm{aabbcc}, 42 \mathrm{bbc}$, $43 \mathrm{bc}, 44 \mathrm{ac}, 45 \mathrm{c}, 62 \mathrm{EF}, 63 \mathrm{ABC}, 65.8 \mathrm{aabb}, 69 \mathrm{ab}, 72 \mathrm{~b}, 74 \mathrm{a}$;

M. $4 a, 5 a, 6 a, 10 b b, 11 b b, 16 b, 17 b, 18 b, 22 d, 23 c, 24 d, 27 a, 34$. iA3, 39a, 52c, 56b, 60b, 81b, 82c, 84b, 97b, 103b, 104a, 11la, $112 \mathrm{e}$;

P. 3dd, 15- $\bar{T}$, numerous.

(2) Figure 29: D. 16bbcc, 17bbcc, 18cc, 19abb, 2la, 23b, 63B.

(3) Figure 34: Tozzer, Lunda, p. 160.

(4) Figure 52: D. 45b, 46d, 55a, 60ab, 72b.

(5) Figure 57: D. 24B, 26a;

M. $40 \mathrm{bb}$;

P. 3acdd, 4abbc, ic, 10bd, 11d.

(6) Figure 72: D. 62CEF, 63ABC, 66a3, 69ג, 70BCD.

(7) Figure 75: D. 42c, 43c, 44c, 45ac, 5la. 


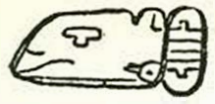

(1) 169.61

Loc. 1

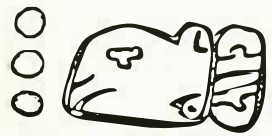

(4) III.169.6I

M. 680

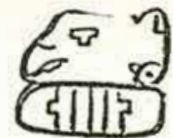

(2) $169: 61$

D. 206

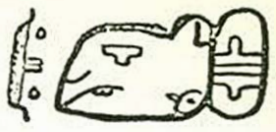

(3) 1.169 .61

M. 182

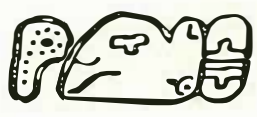

(5) 28.169 .61

P. $16 \mathrm{~b}$

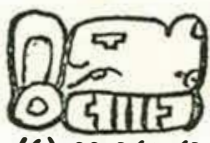

(6) $22.169: 61$

D. $33 b$ $43 a$

$70 D$

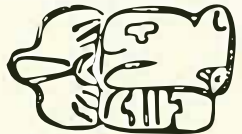

(7) $24.169: 61$

D. $62 \mathrm{D}$

P. $18 \mathrm{c}$

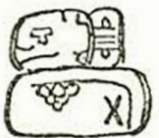

(10) $169.61 / 1339$

M. 37412

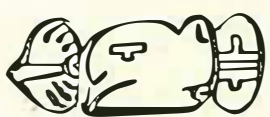

(8) 24.169 .61

D. $34 \pi$ 60D

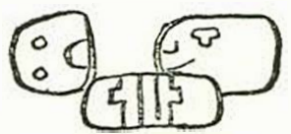

(ב) $203.159: 61$

P. $28 \mathrm{~b}$

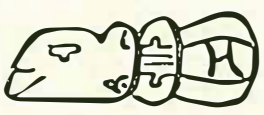

(9) $169.61-13332$

D. $33 c$

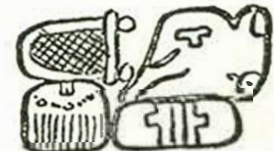

(12) $35.1360-169: 61$

D. 602 $5 \mathrm{C}_{2} 5 ?$ 


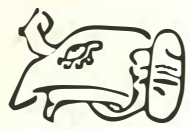

(13) 125.61

D. $\begin{array}{ll}3 a & 36 i \\ 32 c & 370 b\end{array}$

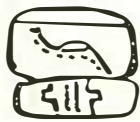

Munve

(16) $1319 ?: 61: 82$

2.. 351

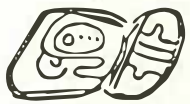

(14) 47.61

D. $31 a$ 732

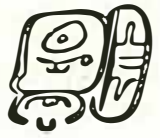

(15) $147.61: 79$

D. $61 \mathrm{~A}$

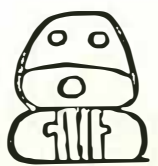

(18) $1320 n: 61$

D. 540

P. $8 \mathrm{c}$

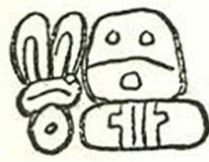

(19) $21.1320 n: 61$

D. $20 \mathrm{c}$ 2625

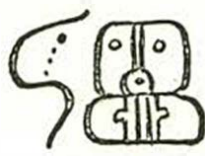

(20) $4.1320: 61$

P. $5 \mathrm{c}$

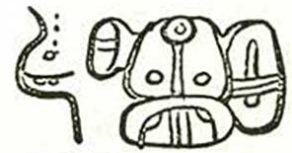

(21) $60.80 .1320 .61: 80$ א. 702

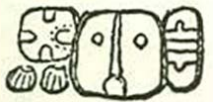

(22) 20.44 .2320 .62

ม. $36 \mathrm{D}$

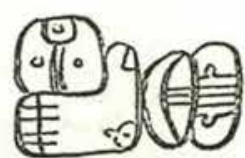

(23) $1320 i / 161.80 .61$

‥ 370

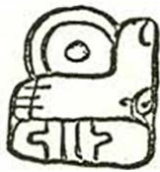

(24) $1329 / 161: 61$

M. 37219 


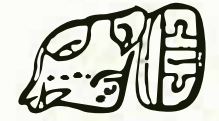

(25) 708.61

D. 570

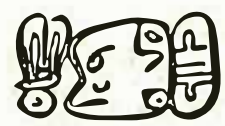

(28) 21.209 .61

D. 280

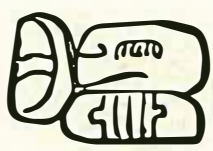

(32) $80.152: 61$

M. 28D

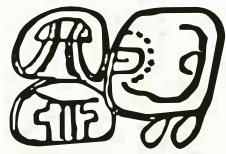

(34) $23332: 61-2339$

Ioc. 3

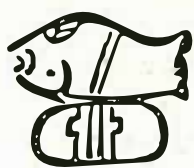

(26) $758: 61$

D. $32 \mathrm{~b}$

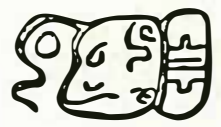

(29) 25.109 .61

Loc. 2

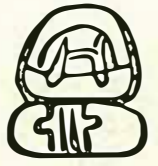

(32) $2333 a: 61$

ม. $95 \mathrm{c}$

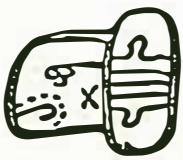

(35) 2339.61

2.. $81 \mathrm{~b}$

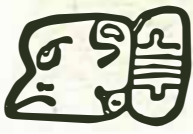

(27) 209.62

$4.52 \mathrm{c}$

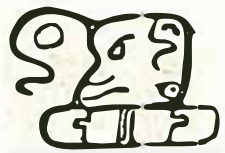

(30) 25.209 .62

D. 2223

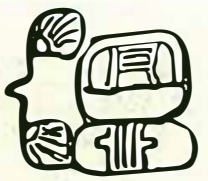

(33) $75.23332: 61$

P. $5 \mathrm{c}$

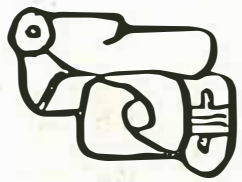

(36) $77: 1317: 61$

4. 36.222 


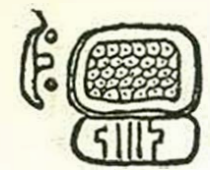

(37) $2.2304: 62$

D. Ic $2 d d$

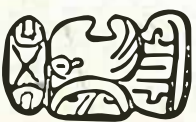

(40) $32.160 .61: 80$

4. 3824

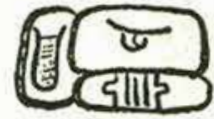

(38) $2.1322: 61$

H. $28 \mathrm{dd}$

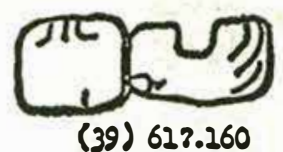

2.. 200

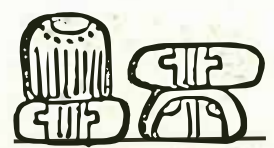

(42) $1321: 61.61: 80$

2. 2022

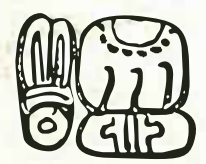

(43) $21.1321: 61$

4. 52

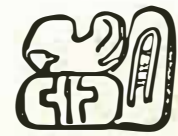

(42) $260: 61-23330$

X. $93 c 0$

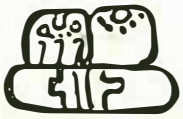

(44) 2360-1321:62

M. 950

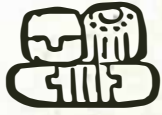

(45) $2324-1321362$

M. 94d

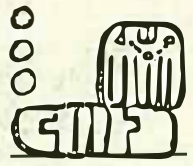

(46) III.2360:62

1. 2040

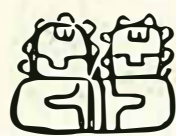

(47) $2324-1324: 62$

D. 40012

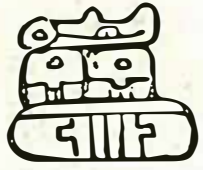

(48) $82: 1324,-2324: 62$

H. 2070 


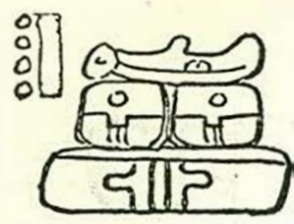

(49) IX.82:1324-1324:61

Si. $206 \mathrm{~b}$

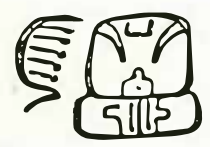

(52) $4.1331: 61$ Loc. 4

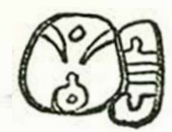

(50) 1331.61

D. $36 \mathrm{~b}$

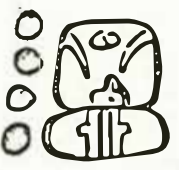

(53) IV.1331:61

D. 692

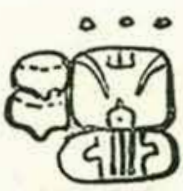

(56) $26.2331: 61$

D. 698

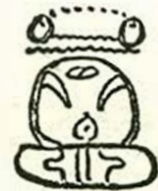

(55) $25: 1331: 61$

D. 698

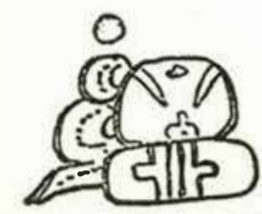

(58) I:29.1331:61

D. 612

P. $3 c c$

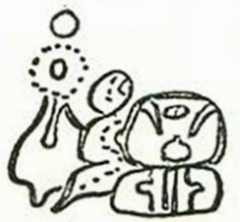

(59) $I: 9.29 .1331: 61$

D. $70 \mathrm{~d}$

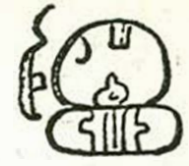

(52) $2.2331: 61$

28. $23 \mathrm{~b}$

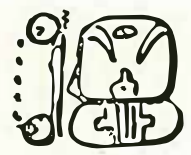

(54) $25.1331: 61$

D. 618

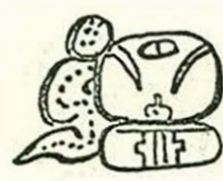

(57) $29.1331: 61$

Loc. 5

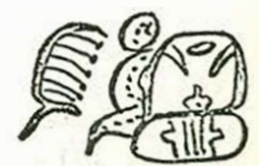

(60) $4.29 .1331: 61$

P. $10 c$ ? 


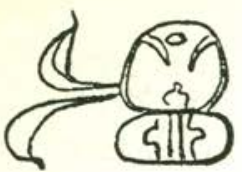

(61) $38.1331: 61$

D. $57 \mathrm{a}$

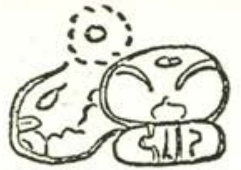

(62) $1301 / 133 ?-1331: 61$

D. $72 a$

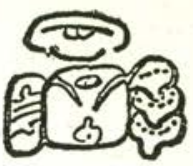

(63) $61.79: 1331.26$

P. 21

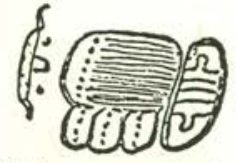

(64) $1.2359 .61: 64$

D. $29 \mathrm{~b}$

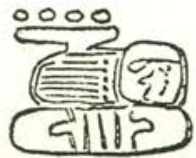

(65) $D x: 1359-2337: 62$

M. 2050

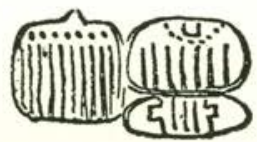

(66) $13591-1360: 61$

D. $30 \mathrm{~b}$

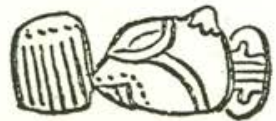

(67) 2359.708 .611

D. $29 \mathrm{~b}$

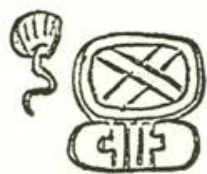

(68) $75.1350: 61$

x. 41215

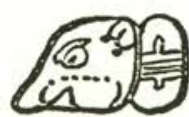

(69) 707.61

D. $32 \mathrm{~b}$ 584

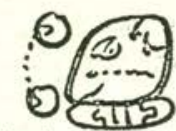

(70) $2.707: 61$

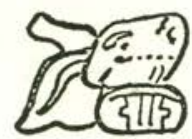

(72) $6.707: 61$
D. $24 \mathrm{BC}$
D. $24 \mathrm{BC}$

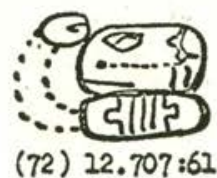

Loc. 6 

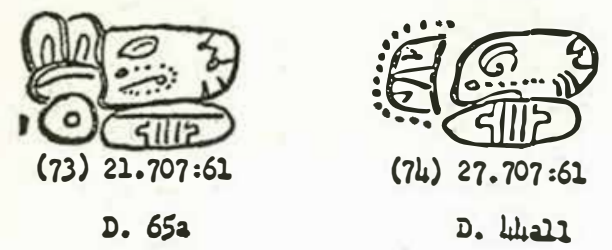
(74) $27.707: 61$
D. 44223
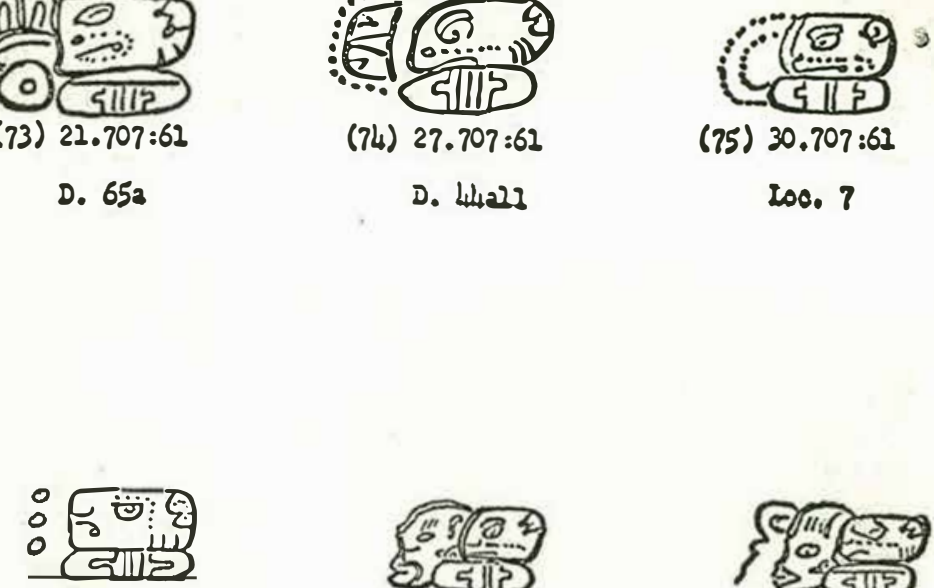

(76) III. 707:61

3. 680

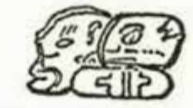

(77) 209-707:61

D. 6205

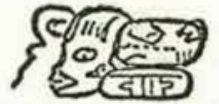

(78) 25.109-707:62

D. 618

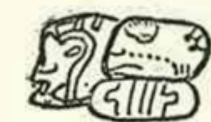

(79) $130-707: 62$

D. 628
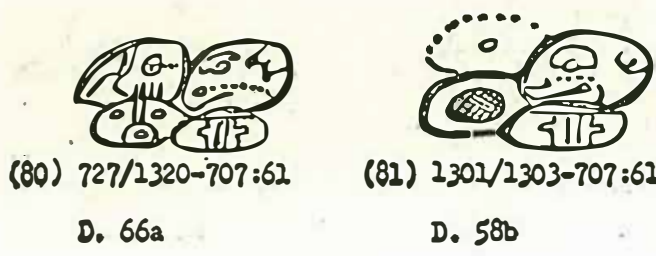

(81) $2301 / 2303-707: 62$

D. $58 b$

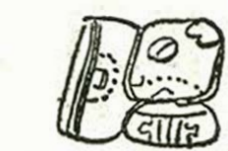

(82) 1313-707:62

D. $58 \mathrm{~b}$

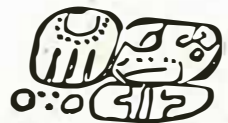

(83) 2321:63-707:62

D. 652

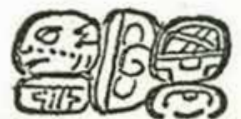

(84) $707: 61-72.2347: 79$

D. 658 


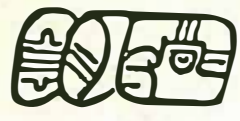

(85) 61.80 .126

M. $24 \mathrm{c}$

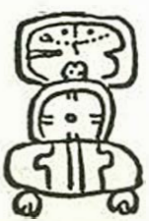

(88) $3: 1341: 61: 2$ ?

M. 8

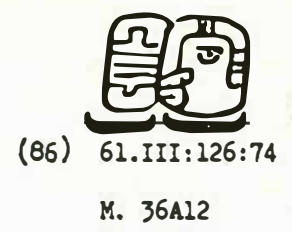

M. $36 \mathrm{Al2}$

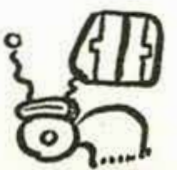

(89) $61 / 36.62$

M. $85 \mathrm{c}$ $87 \mathrm{c}$

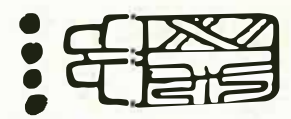

(87) IV.46.1347:61

M. $62 c$

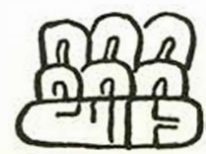

(90) $497: 49 ?: 61$

M. $77 \varepsilon$

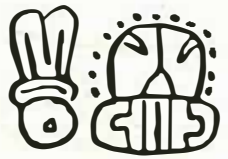

(91) $21.27^{\prime}: 61$

D. $48 \mathrm{c}$

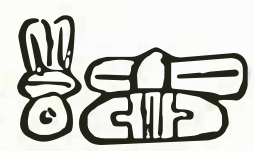

(92) $21.46^{\prime: 61}$

M. $100 \mathrm{dd}$

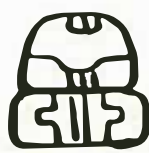

(93) $1324: 61$

M. $77 B$ $78 B \times 6$

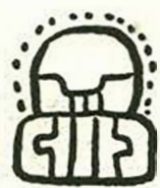

(94) 1324a?:61

M. $77 \mathrm{C}$

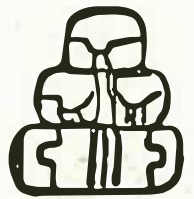

(95) $1324 / 1324-1324: 61$

M. 78BD

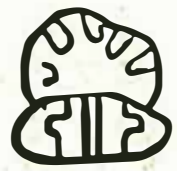

(96) $2: 61$

ive 798 


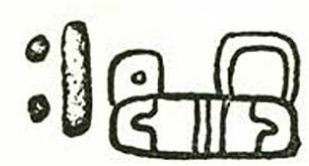

(97) VII.1329-1300:61

M. $82 a$

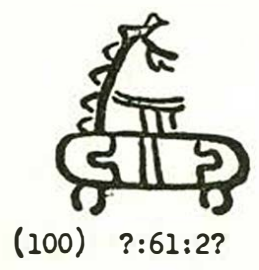

M. 8

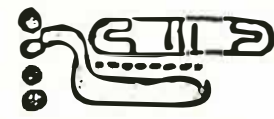

(98) IV.61:?

M. $82 a$

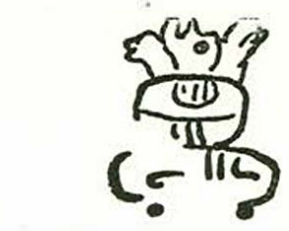

(101) ?/1324:61:2?

M. 8

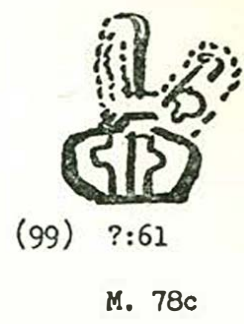

$(0: 02)$

(102) $?: 61$

i1. 78A 